\title{
AN INVESTIGATION OF THE IGNEOUS ROCKS ON HAREØEN AND WESTERN NÛGSSUAQ, WEST GREENLAND
}

\author{
Niels Hald
}

Hareøen is an island north-west of Disko in western Greenland. It has the form of a plateau, whose highest point - 512 metres - is found near the south coast. Like the neighbouring parts of Nûgssuaq and Disko, Hareøen consists chiefly of Tertiary basaltic lavas. The island first attracted attention on account of the presence of interbasaltic, coal-bearing sediments on the north-east coast. These were already examined by Giesecke in 1811 (Giesecke, 1910) and later among others by Steenstrup (1874) and B. E. Koch (1959). A petrographic investigation of the basalts was first undertaken by Holmes (1919), who described loose fragments rich in $\mathrm{K}_{2} \mathrm{O}$. Lavas from the south coast, collected and analysed by Pedersen (1970), also have a high content of potash. V. Münther in the years 1948-49 untertook geological mapping of the island, on which the present investigation is supported (Münther, in press).

The lavas in the West Greenland basalt province are divided into a lower olivineporphyritic formation and an upper, chiefly plagioclase-porphyritic formation (a summary of the geology of the district is found in Rosenkrantz \& Pulvertaft, 1969). Both are known from Hareøen; the lower formation is found only on Niaqua in the east, while the upper formation is known from the rest of the island. They are separated by a fault striking NNE.

The lower formation consists mostly of 1-3 m thick layers of dark grey weathering, vesicular pahoehoe lavas. The layers are most often rich in phenocrysts of olivine. A group of 3-5 flows of reddish-brown weathering, tholeiitic, aphyric aa lavas can be followed for about $2 \mathrm{~km}$. The layers dip $\mathrm{W}$ at about $30^{\circ}$; they are cut by normal faults. The upper formation on Hareøen can be divided into an older chiefly plagioclase-porphyritic group and a younger olivine-porphyritic group. It is cut by a number of faults mostly striking NNE. In several cases the vertical displacement is more than $200 \mathrm{~m}$.

The basalts of the former group are tentatively divided into a number of lithological types. On the western part of the island 5-10 m thick basalts characterised by a large content of augite phenocrysts predominate. This unit is separated by faults from the basalts on the central part of the island. Here, in small areas, 5-10 m thick plagioclase-porphyritic basalts alternate with aphyric basalts. More widespread, however, is a unit with $10-20 \mathrm{~m}$ thick flows of plagioclase-augite-porphyritic 
basalts characterised by large, yellowish brown weathering vesicular and scorious zones. Flows of this type overly on the south-west coast a plagioclase-porphyritic series. The chronological relations between the two types are not known. In two places near Talerua on the north-east coast extrusive layers of acid or intermediate rocks are found.

The layers of the older group are slightly folded. In the central part of the island they dip ESE, while on the north-western part they dip WNW.

The younger olivine-porphyritic group is only known from the south-eastern part of the island. The basalts, which have been described by Pedersen (1970), contain titaniferous augite. The layers are nearly horizontal; they overlie discordantly the basalts of the lower, chiefly plagioclase-porphyritic group.

A few dykes consisting of an aphyric basalt cut the upper formation on the western part of the island. Like the upper olivine-porphyritic basalts they contain titaniferous augite, but the content of olivine is smaller. Like most of the faults, the dykes strike NNE.

Interbasaltic sediments are found, as mentioned above, on the north-eastern coast, and in the low coastal cliffs in the area of land-slides on the south coast. Sediments, including a one metre thick coal layer, are found in situ in a steep gully above the south coast. The layers, which occur at a height of about $275 \mathrm{~m}$, are cut towards the coast by a fault, and can only be followed for about a hundred metres.

In the same gully basalts and Tertiary sediments are overlain at a height of 300 metres by late glacial, well sorted layers of clay, sand, gravel and conglomerate. The upper limit of exposures of the basalt seldom exceeds $300 \mathrm{~m}$. It is presumed therefore that the sediments are widely spread on the southern, highest part of the island, although they are only found in a few other localities.

In connection with the investigation on Hareøen samples were collected on the south-west coast of Nûgssuaq west of Itivdle. It was not possible to correlate the plagioclase-porphyritic lavas there with the above-mentioned lithological units from the upper series on Hareøen. However, a body - possibly a sill - at Nûluk consists of the same type of olivine basalt as the upper lava group on Hareøen. The NNEstriking aphyric dykes continue on Nûgssuaq.

At several horizons in the plagioclase-porphyritic series acid or intermediate rocks were found; especially to be mentioned is a $25 \mathrm{~cm}$ thick greenish ignimbrite with phenocrysts of aenigmatite.

\section{References}

[Giesecke, K. L.] 1910: Karl Ludwig Gieseckes mineralogisches Reisejournal über Grönland 1806-1813. Meddr Grønland 35, 1-478.

Holmes, A. 1919: The basaltic rocks of the Arctic region. Mineralog. Mag. 18, 180-223.

Koch, B. E. 1959: Contribution to the stratigraphy of the non-marine Tertiary deposits on the south coast of the Nûgssuaq peninsula Northwest Greenland. Bull. Gronlands geol. Unders. 22 (also Meddr Gronland 162,1$), 100 \mathrm{pp}$. 
Münther, V. (in press): The West Greenland basalt formation. Results of a geological reconnaissance around Svartenhuk peninsula. Rapp. Grønlands geol. Unders.

Pedersen, A. K. 1970: En petrologisk undersøgelse af tertiære vulkanske bjergarter fra det nordlige Disko. Unpublished prize dissertation, Univ. of Copenhagen. (Reviewed in Festskrift udgivet af Kobenhavns Universitetet $i$ anledning af Universitetets ärsfest, 1970, 379-383).

Rosenkrantz, A. \& Pulvertaft, T. C. R. 1969: Cretaceous-Tertiary stratigraphy and tectonics in northern West Greenland. Mem. Am. Ass. Petrol. Geol. 12, 883-898.

Steenstrup, K. J. V. 1874: Om de kulförende Dannelser paa öen Disko, Hareöen og Syd-Siden af Nûgssuak's Halvöen i Nord-Grönland. Vidensk. Meddr dansk naturh. Foren. Kbh. 1874, Nr. 3-7, 76-112.

\section{CONTINUED INVESTIGATIONS OF QUATERNARY DEPOSITS IN THE AREA BOUNDED BY SØNDRE STRØMFJORD, THE INLAND ICE, AND THE SUKKERTOPPEN ICE CAP}

\section{Norman W. TenBrink}

The 1970 project was a continuation of more general 1969 investigations, some results and the objectives of which were reported by Weidick \& Ten Brink (1969). The objectives of 1970 field work were to: (1) accurately determine altitudes and characteristics of marine limits; (2) complete a collection of marine shells and organic material from emerged marine deposits in order to derive a radiocarbondated delevelling history; (3) obtain cores of sediments from at least three lakes for pollen analysis and C-14 dating of lake-sea isolation times; (4) map in detail some glacial, glaciofluvial, and marine deposits known from 1969 investigations to be particularly important in reconstruction of Holocene events, and (5) conduct a lichenometric survey on young moraines near the Inland Ice in order to estimate ages of the moraines. All the field objectives were achieved, and the results that can be stated before completion of analyses are summarised below.

Marine limits. In general, within the area under consideration, there is a progressive decrease in marine limit with decreasing distance from the present Inland Ice margin. Beginning with the investigated area farthest from the Inland Ice, the marine limit is $120 \pm 10 \mathrm{~m}$ a.s.1. in Aussivit at the head of Itivdleq fjord. (All place names are taken from Danish Geodetic Institute map sheets 66 V.1, 66 V.2 and 67 V.2) The limit is rather well defined in Aussivit by shell-rich silts up to $105 \pm 10 \mathrm{~m}$, and an uppermost strandline $120 \pm 10 \mathrm{~m}$ a.s.l.

In the Angujârtorfik-Angujârtorfiup kûa area, c. $35 \mathrm{~km}$ up Søndre Strømfjord from Aussivit, the marine limit is very difficult to determine precisely, but is definitely greater than $70 \pm 3 \mathrm{~m}$, which is the highest occurrence of unambiguous strandlines, and lower than $134 \pm 10 \mathrm{~m}$, which is the upper limit of terraced sediments filling lower Angujârtorfiup kûa. The local marine limit is tentatively believed to be $115 \pm 10$ $\mathrm{m}$. This judgement is based on the following evidence: (1) $115 \pm 10 \mathrm{~m}$ is the altitude 